\title{
Bilateral Frontal Hemorrhagic Necrosis Associated with Acute Ethanol Poisoning on the Basis of Chronic Alcoholism: Case Report and Review of the Literature
}

\author{
Kronik Alkolizm Zemininde Akut Etil Alkol İntoksikasyonu Sirasında Meydana Gelen \\ Bilateral Frontal Hemorajik Nekroz Olgusu Eşliğinde Literatürün Gözden Geçirilmesi
}

\author{
(1) İrem Taşc1, (1) Meryem Bakır \\ Malatya Training and Research Hospital, Clinic of Neurology, Malatya, Turkey
}

\begin{abstract}
Chronic alcoholism and acute ethanol poisoning have significant effects on the central nervous system. These effects can be divided into two groups. The first effect is the volume loss associated with a toxic effect on neurons mediated by neurotransmitters and/or receptors and electrolytes, and the secondary effects are associated with the sequela of liver cirrhosis such as hepatic encephalopathy and coagulopathies, and the problems in the gastrointestinal tract leading to impairment of vitamin uptake, ultimately leading to Wernicke-Korsakoff syndrome. Herein, we report a 68 -year-old male patient who presented to the emergency room with confusion associated with acute ethanol poisoning on the basis of chronic alcoholism. A brain computed tomography (CT) scan revealed symmetrical hemorrhagic necrosis in bilateral frontal regions. In our case, vasculopathies and infectious etiology were excluded through cerebral and carotid vertebral CT angiography, examinations, and laboratory findings. Investigation of the cause of this atypical radiographic finding revealed that ethanol ingestion leads to increased risk for hypertension, as well as cerebral hemorrhage by resulting in coagulation dysfunction; it triggers P53- and neuron-specific enolase- mediated apoptosis and necrosis, thereby resulting in neuronal damage. Acute and chronic use of ethanol has specific effects on the frontal lobe of the brain. The findings are discussed in light of the relevant literature.
\end{abstract}

Keywords: Ethanol, poisoning, hemorrhagic necrosis, frontal cortex

$\ddot{O} \mathbf{z}$

Kronik alkolizmin ve akut etil alkol intoksikasyonunun santral sinir sistemi (SSS) üzerine etkileri vardır Etil alkolün SSS üzerine etkileri iki şekilde ortaya çıkar. Birincisi reseptörler üzerine olan etkisiyle iyon dengesizliğine sebep olarak oluşturduğu direkt nöronal toksisite, ikinicisi ise vitamin emilim eksikliğine bağlı Wernicke-Korsakoff sendromu, hepatik sistem üzerinden neden olduğu koagülopatilere bağlı etkilenme ve hepatik ensefalopati tablolarıdır. Bu yazıda kronik alkolizm zemininde akut etanol intoksikasyonu gelişen ve bilinç bulanıklı̆̆ı etyolojisi araştırılırken çekilen beyin bilgisayarlı tomografi (BT) de simetrik bifrontal hemorajik nekroz izlenen 68 yaşında bir erkek hasta sunulmuştur. Serebral ve karotis vertebral BT anjiyografi, muayene ve laboratuvar bulguları ile vaskülopatiler ve enfeksiyöz etyolojiler dışlanmıştır. Bu atipik radyolojik bulgunun sebebi araştırıldığında etil alkol kullanımının hipertansiyon riskini artırdığı, koagülasyon faktörlerinde fonksiyon bozukluğu yaparak serebral hemoraji riskini artırması dışında P53 ve nöron spesifik enolaz aracılığılla apopitoz ve nekrozu tetikleyerek nöronal hasara neden olduğu ayrıca etil alkolün akut ve kronik kullanımının beyinde frontal lobu spesifik olarak etkilediği literatür eşliğinde tartışıldı.

Anahtar Kelimeler: Etil alkol, intoksikasyon, hemorajik nekroz, frontal korteks

\section{Introduction}

According to the World Health Organization data, the average pure alcohol consumption per capita was 4.7 liters in the world in 2010. The consumption of alcoholic beverages is approximately one-third of the world average in our country. Deaths that occur due to harmful use of alcohol constitute $4 \%$ (2.5 million) of all deaths (1). Ethyl alcohol may cause stuporcoma between $300-350 \mathrm{mg} / 100 \mathrm{dl}$, and may cause mortality at doses higher than $350 \mathrm{mg} / \mathrm{dl}$. When it is taken together with other substances affecting the central nervous system (CNS), 150-200 $\mathrm{mg} / 100 \mathrm{ml}$ ethyl alcohol in the blood is considered as the minimal lethal dose (2). Alcohol use is associated with different clinical presentations in neurology practice. Alcohol-related neurologic diseases are Wernicke-Korsakoff syndrome (WKS), alcoholic neuropathy, amblyopia, acute intoxication, fetal alcohol syndrome, central pontine myelinolysis, tremor, delirium tremens, cerebellar degeneration, Marchifava-Bignami disease, alcoholic myopathy, and alcoholic dementia (3). The areas that are affected by excessive alcohol consumption in the CNS are the frontal cortex, thalamus, hippocampus pons, and cerebellum (4).

Address for Correspondence/Yazışma Adresi: İrem Taşc MD, Malatya Training and Research Hospital, Clinic of Neurology, Malatya, Turkey Phone: +90 5369550534 E-mail: tasciiirem@gmail.com ORCID: orcid.org/0000-0001-7069-769X

Received/Geliş Tarihi: 17.04.2019 Accepted/Kabul Tarihi: 23.01.2020

${ }^{\circ}$ Copyright 2020 by Turkish Neurological Society

Turkish Journal of Neurology published by Galenos Publishing House. 
Herein, we report a 68 -year-old male patient who presented to the emergency room with confusion associated with acute ethanol poisoning on the basis of chronic alcoholism. The interesting aspect of the present case is that the patient was first considered to have confusion because of a history of ethyl alcohol intoxication with a period of unconsciousness; however, when no response was observed to treatment, brain computed tomography (CT) was performed and a symmetrical bilateral frontal hemorrhage, that this finding has not been presented in this type of case, was detected. Possible etiologies of bilateral frontal hemorrhage were ruled out, and alcohol use was considered to be the actual cause.

\section{Case Report}

A 68-year-old male patient was admitted to our emergency room after initially experiencing nausea, dizziness, and tremor, and subsequently falling to the ground and remaining unresponsive along with having urinary and fecal incontinence. His history revealed that he had ingested 14 bottles of beer $(500 \mathrm{ml}$ each) on the day of the incident and had regularly consumed 5-10 bottles of beer every day for the last 25 years. The patient had been previously hospitalized in a psychiatry clinic twice due to alcohol dependence, but still continued alcohol use. The patient was receiving ramipril $5 \mathrm{mg} /$ day for hypertension and acetylsalicylic acid $100 \mathrm{mg} /$ day for ischemic heart disease. On admission, the patient weighed $75 \mathrm{~kg}$ and his arterial pressure was $80 / 50 \mathrm{~mm} \mathrm{Hg}$, heart rate 98 beats/ $\mathrm{min}$, respiratory rate $12 \mathrm{breaths} / \mathrm{min}$, blood glucose level $140 \mathrm{mg} /$ $\mathrm{dl}$, and temperature was $37.7^{\circ} \mathrm{C}$. Arterial blood gas was consistent with metabolic acidosis ( $\mathrm{pH}$ 7.28). The patient had a blood ethanol level of $177 \mathrm{mg} / 100 \mathrm{ml}$ and was hospitalized in the intensive care unit (ICU) due to a diagnosis of ethanol poisoning. The patient was rapidly resuscitated with fluids. The blood lactate level was 1.2 $\mathrm{mmol} / \mathrm{l}$ and the pyruvic acid level was $0.9 \mathrm{mg} / \mathrm{dl}$, both of which indicated no thiamine deficiency. Even so, prophylactic treatment with intravenous (i.v.) thiamine $1000 \mathrm{mg} /$ day (i.v.) was initiated due to a suspicion of WKS. However, despite the $24 \mathrm{~h} \mathrm{ICU}$ care, fluid replacement and thiamine treatment, the patient showed no improvement in consciousness and was referred to the neurology department. On neurologic examination, the patient had confusion and was unresponsive to verbal commands, had no paralysis on either side, no nystagmus, unrestrained eye movements, no facial asymmetry, backward trunk ataxia while sitting, no neck stiffness, and bilateral extensor plantar responses. No sensory examination could be performed. Based on the laboratory parameters and unresponsiveness to the thiamine treatment, the suspicion of WKS was ruled out. Cranial CT was performed to rule out other intracranial conditions, and symmetrical hemorrhagic necrosis was detected in bilateral frontal regions (Figure 1). Although magnetic resonance imaging (MRI) was planned for further evaluation of the lesions, it could not be performed because the patient had a non-MRI-compatible metal implant. Before the diagnosis was clarified, contrast-enhanced cerebral and carotis-vertebral CT angiography was performed to evaluate the presence of possible vasculopathies that might cause lobar bleeding. No vascular pathology was detected in this respect. Vasculitis markers were observed as negative. Infectious etiology was ruled out because of a lack of neck stiffness and normal C-reactive protein evaluation and hemogram. It was considered that the etiology of hemorrhagic necrosis could be associated with alcohol intoxication based on blood alcohol level measurements and blood gas acidosis data at the time of referral to the clinic due to confusion. The patient was followed up in the ICU for one week and then was transferred to the neurology clinic. On day 15, a repeat brain CT scan showed total resorption of hemorrhage with persisting bilateral frontal hypodensity. On a repeat neurologic examination on day 15 , the patient was fully conscious and had a normal cranial nerve examination, normal muscle strength, normal gait, and bilateral extensor plantar responses.

\section{Discussion}

Orally ingested ethanol is readily absorbed by the gastrointestinal (GI) tract via passive diffusion through the stomach wall. After absorption, ethanol is not bound to plasma proteins and thus easily diffuses into all body fluids. The concentration of ethanol in blood and cerebrospinal fluid is almost the same. Ethanol is rapidly oxidized in the liver by three enzyme systems including cytosolic alcohol dehydrogenase, the microsomal ethanol-oxidizing system, and the peroxisomal system. These systems produce acetaldehyde, which is rapidly oxidized to acetate (5).

The effects of ethanol on the CNS can be divided into two groups. The first effect, which is the principal or "direct" effect, is the volume loss associated with a toxic effect on neurons mediated by neurotransmitters and/or receptors and electrolytes. The

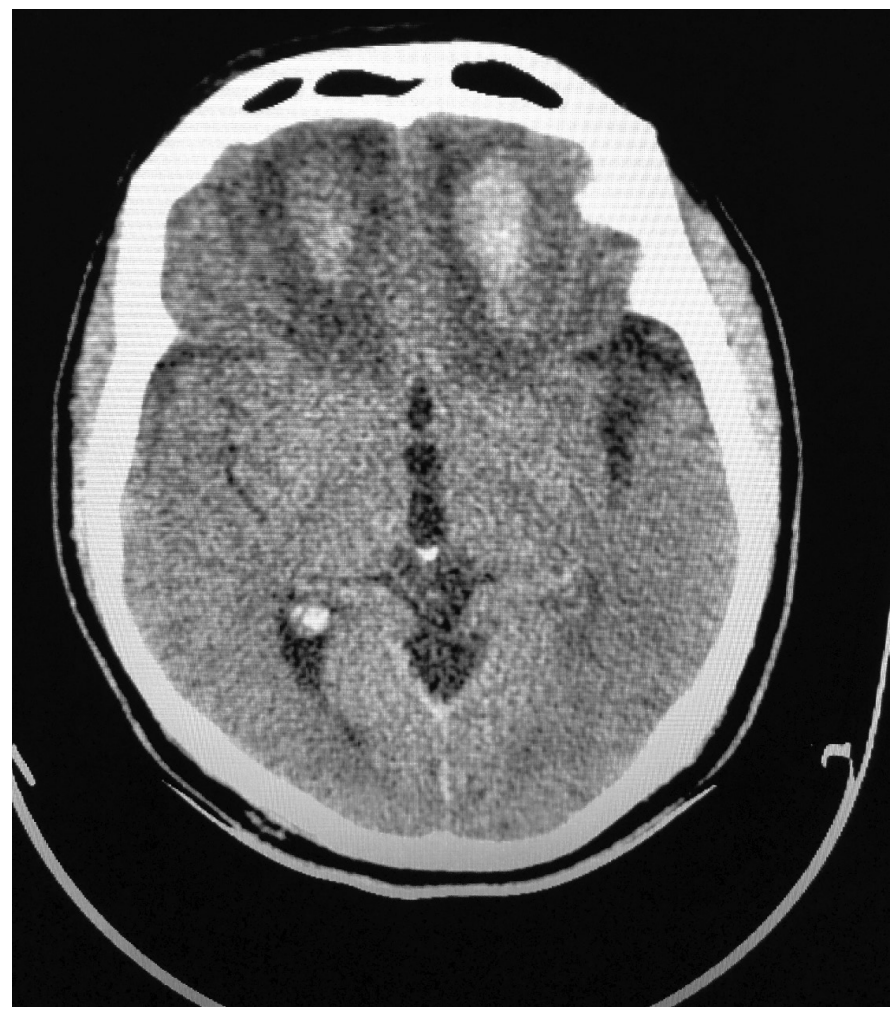

Figure 1. Cranial computed tomography (CT) was performed to rule out other intracranial conditions, and symmetrical hemorrhagic necrosis was detected in bilateral frontal regions

CT: Computed tomography 
secondary effects, however, are associated with the sequela of liver cirrhosis such as hepatic encephalopathy and coagulopathies, and problems in the GI tract leading to impairment of vitamin uptake (6).

Chronic alcoholism and acute ethanol poisoning have serious effects on the CNS (7). It has been extensively shown that excessive ethanol ingestion is a significant risk factor for all subtypes of stroke, predominantly hemorrhagic stroke (8). Moreover, excessive ethanol ingestion has been shown to be an important risk factor for intracerebral hemorrhage and subarachnoid hemorrhage. O'Connor et al. (7) evaluated 156 cases of ethanol and sympathomimetic drug abuse and reported that the risk of intracranial hemorrhage (ICH) was associated with the amount of ethanol ingested within the last $24 \mathrm{~h}$; consumption of 1-40, 41-120, or $>120 \mathrm{~g}$ of ethanol within $24 \mathrm{~h}$ increased the ICH risk by $0.3,2.5$, and 4.8 times, respectively, compared with individuals who used no ethanol. The authors concluded that ethanol inhibited platelet aggregation and led to arterial thrombus formation and thrombolysis.

Chronic alcoholism contributes to the development of liver disease, thereby resulting in liver failure, synthesis of fibrinolytic factors, and various blood-clotting factor disorders, ultimately leading to spontaneous ICH. Peng et al. (8) evaluated 524 heavy drinkers with mild liver disease and divided the patients into 4 groups as (I) heavy drinkers with mild liver disease, (II) heavy drinkers, (III) cases of mild liver disease alone, and (IV) and non-heavy drinkers (moderate drinkers). The authors indicated that the risk of $\mathrm{ICH}$ was the highest among heavy drinkers with mild liver disease and was the lowest among non-heavy drinkers. Moreover, although the risk of ICH was also remarkably high among heavy drinkers and those with mild liver diseases alone, no significant difference was found between the two groups. Similarly, previous studies also indicated that the risk of hypertension was twice higher in heavy drinkers than in nondrinkers (7).

The first radiologic evaluation may be performed with brain CT in patients admitted with loss of consciousness and who are considered to have alcohol intoxication. Brain CT may indicate brain edema, which may occur as a result of alcohol intoxication, and is characterized by symmetrical hypodensity in the white matter and deletion of the subarachnoid distance. Brain CT is useful in such patients for demonstrating brain edema and to exclude changes that may occur because of accompanying trauma; however, the sensitivity and specificity are not sufficient. Brain $\mathrm{MRI}$ is required to evaluate more complicated cases like recurrent convulsions or suspected chronic secondary CNS injury. Brain MRI may show central pontine/extrapontine myelinolysis findings. Signal increase and diffusion restriction may also be detected in T2 and FLAIR-weighted images. Isolated symmetrical pontine lesions are observed in circa $50 \%$ of such patients. Extrapontine lesions may also be detected rarely in the cerebellum, striatum, thalamus - and more rarely - in the cortex, juxtacortical white matter, and in the internal and external capsule fibers. Hemorrhagic lesions may develop with the disruption of the blood-brain barrier (9).

In the case presented, symmetrical hemorrhagic necrosis was also detected, though in bilateral frontal regions. Hypertensive hematoma, trauma, peripheral or subarachnoid aneurysms, sinus vein thrombosis, arteriovenous fistulas, vasculopathies, CNS tumors, infections, autoimmune diseases must be considered in the differential diagnosis of bilateral frontal hemorrhage (10). In our case, vasculopathies and infectious etiology were excluded through cerebral and carotid vertebral CT angiography, examinations, and laboratory findings. There are no articles or case reports in the literature on symmetrical bilateral hemorrhage in the CNS because of ethanol intoxication, but numerous cases of bilateral hemorrhagic necrosis associated with methanol poisoning have been reported in the literature. In all these cases, hemorrhagic necrosis was considered to be caused by the metabolites of methanol (formic acid and formaldehyde) and to arise from intracellular calcium deposition associated with the decreased NA/KATPase activity resulting from the inhibition of cytochrome oxidase by formic acid. On the other hand, putaminal hemorrhagic necrosis was considered to be associated with excessive formic acid deposition in the putaminal region as a result of inadequate venous flow or inadequate arterial circulation $(11,12)$.

In an experimental animal study, Oyinboa et al. (13) evaluated ethanol-induced neurodegeneration of the hippocampus in rats and found that ethanol led to neuronal damage associated with apoptosis and necrosis in the hippocampus and prefrontal cortex, mediated by p53 and neuron-specific enolase (NSE) compared with control and treatment groups.

Nicolás et al. (14) investigated the acute and chronic effects of ethanol ingestion on brain tissue by using single-photon emission CT (SPECT). The authors revealed that immediately after ethanol ingestion, a significant decrease occurred in cerebral blood flow as a result of elevated circulating catecholamine levels, and also that elevated plasma ethanol concentrations upregulated intracellular calcium activity through its effect on the voltage-gated calcium channels in muscle fibers, ultimately leading to cerebral vasospasm. In the same study, SPECT revealed that some parts of the brain were affected more than others. In our patient, the frontal regions were the most affected parts, followed by temporal regions. In the study by Nicolás et al. (14), however, alcoholics exhibited significant frontal lobe atrophy and this finding was associated with chronic hypoperfusion of the frontal region.

The patient presented was admitted to the emergency room due to confusion associated with acute ethanol poisoning on the basis of chronic alcoholism. Despite a prediagnosis of hypertension on admission, the patient was found to be hypotensive on physical examination. Although the patient received ethanol poisoning treatment and thiamine replacement therapy, he showed no improvement, and a brain CT scan revealed symmetrical hemorrhagic necrosis in bilateral frontal regions. The first radiologic evaluation in patients admitted with loss of consciousness who are considered to have alcohol intoxication may be brain CT because of its short examination period and it is easily accessible. An investigation of the cause of this atypical radiographic finding revealed that ethanol ingestion leads to increased risk for hypertension as well as cerebral hemorrhage by resulting in coagulation dysfunction; it triggers P53- and NSEmediated apoptosis and necrosis, thereby resulting in neuronal damage. Acute and chronic use of ethanol has specific effects on the frontal lobe of the brain.

\section{Ethics}

Informed Consent: A written consent form was obtained from the patient. 
Peer-review: Externally peer-reviewed.

\section{Authorship Contributions}

Concept: İ.T., Design: İ.T., Data Collection or Processing: M.B., Analysis or Interpretation: İ.T., Literature Search: M.B., Writing: İ.T., M.B.

Conflict of Interest: No conflict of interest was declared by the authors.

Financial Disclosure: The authors declared that this study received no financial support.

\section{References}

1. Buzrul S. Türkiye'de Alkollü İçki Tüketimi. Journal of Food and Health Science 2016: 2:112-122.

2. Baduroğlu E, Durak D. Alkol İle İlgili Adli Tip Sorunları. Uludağ Üniversitesi Tip Fakültesi Dergisi 2010; 36:65-71.

3. Bilgiç B, Yazıcı J. Sinir Sisteminin Toksik ve Nutrisyonel Hastalıkları. In: Öge EA, Baykan B (eds). Nöroloji $2^{\text {nd }}$ ed. İstanbul: Nobel Tip Kitabevleri, 2011:599

4. Zhao Q, Fritz M, Pfefferbaum A, Sullivan EV, Pohl KM, Zahr NM. Jacobian Maps Reveal Under-reported Brain Regions Sensitive to Extreme Binge Ethanol Intoxication in the Rat. Front Neuroanat 2018;12:108.

5. Ol KK. Prenatal ve postnatal alkol kullanımı sonucunda rat beyinlerinde oluşan nörodejenerasyonun betain ve/veya omega-3 uygulanmasiyla önlenmesinin araştırılması (Doktora tezi). Eskişehir: Eskişehir Osmangazi Üniversitesi Sağlık Bilimleri Enstitüsü Tıbbi Biyokimya Anabilim Dalı; 2014.
6. Geibprasert S, Gallucci M, Krings T. Alcohol-induced changes in the brain as assessed by MRI and CT. Eur Radiol 2010;20:1492-1501.

7. O'Connor AD, Rusyniak DE, Bruno A. Cerebrovascular and cardiovascular complications of alcohol and sympathomimetic drug abuse. Med Clin North Am 2005;89:1343:1358.

8. Peng GS, Yin SJ, Cheng CA, et al. Increased risk of cerebral hemorrhage in Chinese male heavy drinkers with mild liver disorder. Cerebrovasc Dis 2007;23:309-314.

9. Keil VC, Greschus S, Schneider C, Hadizadeh DR, Schild HH. The Whole Spectrum of Alcohol-Related Changes in the CNS: Practical MR and CT Imaging Guidelines for Daily Clinical Use. Rofo 2015;187:1073-1083.

10. Johnson SA, Cox B, Ho ML, Murphy M, Scharf E. Anterior Cranial Fossa Dural Arteriovenous Fistula Presenting as Recurrent Multifocal Lobar Intracerebral Hemorrhages: A Case Report. Neurohospitalist 2019;9:109112.

11. Thirunavukkarasu S, Nair PP, Wadwekar V. Acute bilateral putaminal haemorrhagic necrosis in methanol poisoning. BMJ Case Rep 2013; pii:bcr2013201026.

12. Keklikoğlu HD, Yoldaş TK, Çoruh Y. Methanol Poisoning and Putaminal Hemorrhage: Case Report. Journal of Neurological Sciences 2007;13:338342.

13. Oyinboa CA, Robert FO, Avwioro OG, Igbigbi PS. Jobelyn suppresses hippocampal neuronal apoptosis and necrosis in experimental alcoholinduced brain stress. Pathophysiology 2018; 25:217-325.

14. Nicolás JM, Catafau AM, Estruch R, et al. Regional cerebral blood flowSPECT in chronic alcoholism: relation to neuropsychological testing. J Nucl Med 1993;34:1452-1459. 